\title{
УДК 374.71
}

https://doi.org/10.52058/2786-4952 -2021-5(5)-837-848

Цегельник Тетяна Миколаївна викладач кафедри дошкільної педагогіки, психології та фахових методик, Хмельницька гуманітарнопедагогічна академія, вул. Проскурівського підпілля, 139, м. Хмельницький, 29013, тел.: (096) 627-80-08, e-mail: sveettana@ukr.net, https://orcid.org/00000001-7643-02-08

Глоба Лідія Григорівна кандидатка педагогічних наук, доцентка, Комунальний заклад вищої освіти «Ужгородський інститут культури i мистецтв» Закарпатської обласної ради, вул. Челюскінців, 2, м. Ужгород, 88000, тел.: (050) 293-51-47, e-mail: e-mail:lidiia.hloba@uica.education, https://orcid.org/0000-0002-2870-2798

Чусова Ольга Миколаївна кандидат педагогічних наук, психології та фахових методик, Національний університет «Одеська політехніка», проспект Шевченка, 1, м. Одеса, 65044, тел.: (066) 557-27-29, e-mail: chusova.olga55@gmail.com, https://orcid.org/0000-0003-1943-109X

\section{ПІДГОТОВКА МАЙБУТНІХ ПСИХОЛОГІВ ТА СОЦІАЛЬНИХ ПРАЦІВНИКІВ ДО РОБОТИ 3 ЛЮДЬМИ 3 ІНВАЛІДНІСТЮ}

Анотація. Зважаючи на той факт, що показник людей які мають обмежені фізичні можливості як у всьому світі, так і на території України невпинно зростає, актуальності набуває питання підтримки даних осіб у соціальному та психологічному аспектах. Соціальна підтримка, як правило, здійснюється працівниками соціальної галузі, які організовують та спрямовують роботу таким чином, щоб задовольнити базові потреби осіб з обмеженими можливостями та надати їм необхідний рівень підтримки. Психологічна підтримка надається психологами, які організовують не лише психологічну підтримку осіб з обмеженими можливостями, а й здійснюють психологічний супровід під час подолання ними психічних криз, або для виведення даних осіб 3 депресивного стану. Якісна підготовка фахівців даних професій вимагає визначення специфічних особливостей взаємодії із особами, що мають фізичні вади. Спільними особливостями як при підготовці психологів так і соціальних працівників $\epsilon$ те, що теоретичні знання вони набувають під час навчання у закладах вищої освіти. В цей період їх освітньої діяльності формується теоретична база знань та елементарні навички практичної діяльності. Подальша підготовка висококваліфікованих працівників є можливою лише тоді, коли здійснюється навчання за вузькою профільною спрямованістю. Кожна $з$ підготовок фахівця в галузі психології або соціальної роботи має свої 
специфічні особливості. Так, при підготовці соціального працівника будь-яка підготовка не дасть позитивних результатів за умови, що людина, яка обрала дану професію не має відповідних людських якостей. Навіть, маючи фундаментальні знання, але не проявляючи елементарного співчуття до осіб, які мають фізичні вади, соціальний працівник не зможе надати людині тієї підтримки, на яку вона очікує. Коли ж справа стосується психологів, то лише за умови сформованих базових знань 3 психології можливе формування навичок активної взаємодії із людьми, які мають обмежені фізичні можливості, за умови, що психолог не виявляе зацікавленість особою, 3 якою встановлюється взаємодія, позитивних результатів від діяльності психолога не варто і чекати.

Ключові слова: майбутній психолог, майбутній соціальний працівник, люди 3 обмеженими фізичними можливостями, люди 3 інвалідністю, професійна підготовка

Tsegelnyk Tetyana Mykolaivna Lecturer of the Department of Preschool Pedagogy, Psychology and Professional Methods, Khmelnytskyi HumanitarianPedagogical Academy, Proskuriv Underground St., 139, Khmelnytskyi, 29013, tel.: (096) 627-80-08, e-mail: sveettana@ukr.net, https://orcid.org/0000-0001-7643-02-08

Hloba Lidiia Hryhorivna Candidate of pedagogical science, position of associate professor, Municipal establishment of Higher Education "Uzhhorod Institute of Culture and Arts", Cheliuskintsev St., 2, Uzhhorod, 88000, tel.: (050) 293-51-47, e-mail: e-mail:lidiia.hloba@uica.education, https://orcid.org/00000002-2870-2798

Chusova Olga Mykolaivna Candidate of pedagogical sciencer, the Senior lecturer of the Psychology and Social Work Department, Odessa Polytechnic National University, Shevchenko Ave., 1, Odessa, 65044, tel.: (066) 557-27-29, e-mail: chusova.olga55@gmail.com, https://orcid.org/0000-0003-1943-109X

\section{PREPARATION OF FUTURE PSYCHOLOGISTS AND SOCIAL WORKERS TO WORK WITH PEOPLE WITH DISABILITIES}

Abstract. Due to the fact that the number of people with disabilities both around the world and in Ukraine is constantly growing, the issue of supporting these people in social and psychological aspects is becoming increasingly important. Social support is usually provided by social workers, who organize and direct work in such a way as to meet the basic needs of people with disabilities and provide them with the necessary level of support. Psychological support is provided by psychologists, who organize not only psychological support for people with disabilities, but also provide psychological support when overcoming mental crises, or to bring these people out of depression. Qualitative training of specialists in these 
professions requires the definition of specific features of interaction with people with physical disabilities. The common features of both the training of psychologists and social workers are that they acquire theoretical knowledge while studying in higher education institutions. During this period of their educational activity the theoretical base of knowledge and elementary skills of practical activity is formed. Further training of highly qualified workers is possible only when training in a narrow profile. Each of the training of a specialist in psychology or social work has its own specific features. Thus, in the training of a social worker, any training will not give positive results, provided that the person who chose this profession does not have the appropriate human qualities. Even with basic knowledge, but without basic compassion for people with disabilities, a social worker will not be able to provide the person with the support he or she expects. When it comes to psychologists, only if the basic knowledge of psychology is formed, it is possible to develop skills of active interaction with people with disabilities, provided that the psychologist is not interested in the person with whom the interaction is established, positive results from the psychologist and wait.

Keywords: future psychologist, future social worker, people with disabilities, people with disabilities, vocational training.

Постановка проблеми. Сучасний світ у всій його красі та 3 високим рівнем технічного розвитку доволі часто залишає поза увагою людей, які мають спеціальні фізіологічні потреби. Число таких людей постійно зростає, а причини виникнення або прояву інвалідності абсолютно різні. Дані $\mathrm{OOH}$ свідчать, що в світі кожна четверта сім'я зіштовхується з даною проблемою, а загальний світовий показник людей, які мають певні фізіологічні можливості перевищує 600 млн. осіб, при чому дітей, які входять до даної групи, понад $25 \%$ від загальної кількості осіб з обмеженими фізіологічними потребами.

В Україні понад 2,8 млн або 6,1\% від загальної чисельності населення, 3 яких майже $80 \%$ людей з інвалідністю - працездатного віку. На жаль, кількість людей 3 інвалідністю в нашій країні 3 кожним роком збільшується. Десять років тому, наприклад, їхня кількість становила 5,3\%. Наразі ситуацію погіршують наслідки бойових дій на сході України, що неминуче призводить до збільшення кількості людей з інвалідністю [1].

Вирішення такої проблеми як інклюзія потребує значних змін у всій системі професійної освіти для роботи 3 людьми, особливо 3 дітьми 3 обмеженими можливостями. Широке впровадження інклюзивного підходу в загальноосвітніх навчальних закладах України потребує змін у підготовці фахівців, які в майбутньому працюватимуть 3 цією групою населення. Підготовка спеціалістів, які мали б належний професійний рівень та могли б займатись такою діяльністю набуває особливого значення. Зважаючи на той факт, що у більшості країн світу проблемами інклюзії та робота 3 людьми 3 обмеженими фізичними можливостями покладається на соціальних працівників, виникає потреба у якісній підготовці соціальних працівників до 
даного виду діяльності [2].

Крім того, що люди з обмеженими фізичними можливостями потребують допомоги з боку соціальних працівників, не менш значимим є психологічна підтримка та психологічний супровід 3 боку психологів. Професійна підготовка майбутніх психологів є однією з центральних тем теорії, науки і практики психології. Дослідники та фахівці, які оцінюють освітню систему, роблять висновки про кризу підготовки психологів. Криза проявляється в тому, що ступінь підготовки випускників вишів у нашій країні не відповідає вимогам суспільства та міжнародним стандартам. Сучасна професійна підготовка не орієнтується на якісні показники, нові принципи та технології навчання. Між загальнокультурними і професійними компонентами навчання існує розрив, що не гарантує формування професійної культури психолога, його підготовки до професійної діяльності, зокрема при роботі із з людьми, що мають обмежені можливості [3].

Аналіз останніх досліджень і публікацій. Чимало робіт присвячено вивченню проблеми інклюзії, але більшість із них - це роботи спрямовані на дослідження особливостей інклюзивної освіти, впровадження в освітній простір технологій, які б дозволили спростити навчальний процес для людей 3 обмеженими можливостями. Серед науковців, які досліджували дане питання Айбазова М., Блінов Л., Воробієнко П., Дятленко Н., Крикун А., Кучерук О., Овсяннікова С., Першко Г., Синьова Є., Таранченко О., Чайковський М. та інші.

Проблему соціально-педагогічної взаємодії 3 дітьми 3 особливими потребами досліджували та описували Капська А., аракова Л., Безпалько О., Шипіцина Л., Кравченко Р., Шульга В та інші.

Психолого-педагогічні аспекти підготовки спеціалістів до роботи 3 людьми з особливими потребами висвітлювали Нечаєв М., Білозерцев $€$., Гонєєв О., Пашков А., Сластьонін В. Вимоги, які висуваються до майбутнього фахівця та несуть соціально психологічний характер були описані такими сучасними педагогами як Абдуліна О., Згрязкіна Н., Беспалько В., Татур Ю., Кухарєв Н., Степанова Г Рибокова М. та іншими.

Мета статті: визначити особливості ефективної підготовки психологів та соціальних працівників до роботи 3 людьми, що мають обмежені фізичні можливості.

Виклад основного матеріалу. Приєднання України до Європи відзначилось не лише політичними та економічними змінами, а й змінами культурного та гуманітарного характеру. Зокрема, має кардинально змінитися ставлення до важливої категорії членів нашого суспільства, а саме до людей 3 обмеженими можливостями.

В Україні майже 8-\% людей, які мають обмежені фізичні можливості - це люди працездатного віку. Останнім часом до цієї категорії інвалідів приєдналася значна кількість воїнів. Здебільшого це молоді люди 3 активною життєвою позицією, але їх життєва ситуація докорінно змінилася з набуттям інвалідності [2]. 
Традиційно вважається, що люди з обмеженими можливостями мають певні проблеми зі здоров'ям, які потребують догляду протягом усього життя. Проте, як в академічних колах, так і в суспільстві набуває авторитету нове бачення того, що люди 3 обмеженими можливостями повинні бути незалежними і що акцент має бути зроблений на організації взаємодопомоги та підтримки людей 3 обмеженими можливостями, коли вони стикаються 3 життєвими труднощами. Це бачення є основою соціальної моделі інвалідності.

Соціальна модель інвалідності визначає інвалідність як набір бар'єрів для ставлення, поведінки та простору, які заважають людям 3 інвалідністю повноцінно брати участь у житті суспільства. 3 суспільно-політичної точки зору люди з інвалідністю становлять меншість, права якої обмежені певними соціальними бар'єрами, створеними більшістю. Більшість також відповідає за їх усунення [2].

Подолання бар'єрів, які виникають перед людьми 3 обмеженими можливостями можливе за умови якісної соціальної та психологічної підтримки. Соціальна та психологічна підтримка людей 3 обмеженими фізичними можливостями здійснюється соціальним працівником та психологом, який може надавати психологічну підтримку або здійснювати психологічний супровід особи, під час подолання нею чергового бар'єру або до моменту виходу із кризової ситуації.

Важливим завданням вільної економічної зони є професійна підготовка майбутніх кваліфікованих працівників. В. Давидов визначає професійну підготовку як одиницю практики та теорії з подальшим позитивним впливом на особистість. Н. Нічкало у своїй роботі зазначав, що професійна підготовка майбутніх спеціалістів має бути орієнтована на розвиток особистісно-творчої особистості [5].

Розглянемо особливості підготовки майбутніх соціальних працівників та психологів до активної взаємодії із людьми із обмеженими фізичними можливостями.

В Україні підготовка соціальних працівників розпочалася лише у 1990-х роках [3], тому підготовка соціальних працівників вимагає використання досвіду інших країн. У 1992 році було засновано Українську асоціацію соціальних педагогів і соціальних працівників, яка в 1994 році приєдналася до Міжнародної асоціації соціальних працівників, а в 1998 році за підтримки ЮНІСЕФ та за активної участі Християнського дитячого фонду започаткувала проект соціальної освіти в Україні. На сьогоднішній день в Україні створено професійні центри в навчальних закладах та пройшли навчання сотні соціальних працівників, соціальних педагогів, тренерів та волонтерів [5].

На сучасному етапі розвитку українського суспільства можна 3 впевненістю говорити про те, що соціальна робота перебуває на піку свого розвитку. Клименюк Н. характеризує соціальну роботу як складний процес, який грунтується на глибокому розумінні соціальним працівником життя людини [6]. У словнику - довіднику соціального працівника соціальна робота 
має одразу три трактування:

1) вид професійної діяльності, спрямованої на за задоволення соціально-гарантованих і особистісних потреб окремих груп людей; створення таких умов, які сприятимуть відновленню функціональної активності особистості або поліпшенню рівня їі працездатності;

2) наука, що характеризується діяльністю, спрямованою на систематизацію теоретичних знань у аспекті поліпшення життя людей 3 обмеженими фізичними можливостями;

3) навчальна дисципліна, яка спрямована на формування цілісного уявлення про особливості та зміст соціальної роботи у майбутніх фахівців даної галузі [7].

Професійна підготовка майбутніх працівників соціальної сфери здійснюється у вищих навчальних закладах. Освітнє середовище університету може функціонувати як простір, у якому багатовекторні механізми взаємодії та комунікації підкреслюють поєднання традиційних та інноваційних принципів організації навчання та виховання здобувачів освіти. Розвиток його інноваційності відбувається насамперед через зміцнення традиційної педагогічної підготовки через інноваційний характер діяльності здобувачів освіти - майбутніх соціальних працівників та на зміцненні партнерських відносин із спеціалістами соціальних установ (організацій) державного та недержавного підпорядкування, які є безпосередніми носіями інноваційного досвіду соціальної роботи. Актуальність такого виду діяльності зумовлена вимогами, які роботодавці висувають до майбутніх фахівців під час становлення взаємозв'язків між закладами вищої освіти та соціальними організаціями, які залучають здобувачів освіти до набуття практичного досвіду [1].

Соціальна робота, як і будь-який інший вид діяльності, потребує ряду різних умов і факторів, які повинні сприяти ㄲi ефективному здійсненню. Поперше, специфіка соціальної роботи вимагає особливої розумової обдарованості, емпатії, вміння концентруватися на потребах і проблемах інших. Зрозуміло, що формування та розвиток даних якостей на рівні навчальних закладів просто не можливі, але без цих рис підготовка соціального працівника, який зможе надавати підтримку особам з обмеженими фізичними можливостями просто не можлива.

За умови якісної та ретельної підготовки працівника соціальної сфери, варто розуміти, що дана людина повинна володіти базовими знаннями з різних галузей, зокрема: медицини, інформатики, права, педагогіки, фізіології, психологіï, відзначатись високим рівнем культури та високими комунікаційними властивостями. Майбутній соціальний працівник повинен володіти навичками критичного мислення, що дозволить аналізувати свої дії та визначати їх можливі наслідки, повинен бути відкритим та викликати у людей довіру, вміння зберігати холодний розум у критичних ситуаціях $\mathrm{i}$ діяти в інтересах особи, відносно якої приймається рішення. Холостова Є. виділяє 
наступні групи найбільш значимих якостей соціального працівника: психоаналітичні, психолого-педагогічні, особиста привабливість [8].

Як вже зазначалось, перша група вимог визначається специфічністю психічних процесів, тому здобуття професії працівника соціальної сфери під силу далеко не кожному.

Друга група вимог грунтується на знаннях, які, відповідно до чинних освітніх програм та законодавчої бази, майбутній соціальний працівник отримує під час навчання в вищому навчальному закладі. Процес навчання диференційований та передбачає поступове вивчення механізмів взаємодії 3 різними групами населення. Взаємодія 3 людьми 3 обмеженими фізичним можливостями розглядається в трьох аспектах:

1) взаємодія 3 дітьми 3 обмеженими можливостями;

2) взаємодія з особами працездатного віку, які мають вроджену або набуту інвалідність;

3) взаємодія з людьми похилого віку, що мають вади фізичного розвитку.

Залежно від вікового показника, взаємодія носить різний характер. Так, наприклад, при роботі 3 дітьми 3 обмеженими можливостями соціальний працівник організовує роботу, спрямовану на залучення дитини до процесу соціалізації, що дозволяє ій відчути себе частиною суспільства. У роботі 3 людьми похилого віку, у більшості випадків, робота соціального працівника спрямована на організаційну діяльність задля задоволення базових потреб людини, наданні їй підтримки та догляді за нею.

Третя група вимог побудована на формуванні особистої привабливості соціального працівника. Даний критерій грунтується на комплексному сприйнятті попередніх двох. Так, соціальний працівник привабливий зовні, але, не маючи відповідної підготовки і не маючи необхідного рівня знань, автоматично втрачає свою привабливість. 3 іншого боку, якщо людина, яка працює в соціальній сфері, не виявляє елементарного співчуття i не переймається ситуацією особи, яка звернулась за допомогою, але при цьому знає всі теоретичні та практичні механізми взаємодії з людьми з обмеженими можливостями, вона втрачає свою привабливість через «холодність» у спілкуванні [9].

Узагальнюючи, варто відмітити, що якісну підготовку працівника соціальної сфери до роботи як 3 людьми 3 особливими потребами так і до соціальної роботи загалом можна підготувати лише тоді, коли людина має необхідний набір людських якостей.

Аналіз наукових досліджень показує, що сучасна освіта включає два види підготовки майбутніх фахівців: інноваційний та традиційний. Перший має на меті встановлення нерозривного зв'язку між умінням передбачати й прогнозувати події, вибором альтернатив та активною участю окремих осіб чи організацій у навчальному процесі, другий - підтримкою існуючої системи навчання. 
Журнал«Герспективита іновації науки»

(Серія«Гедагогіка»), Серія«ГТихологія», Серія «Медицина»

№5(5) 2021

У своїх працях Носков В.І. відмічає, що підготовка сучасних психологів просто не можлива за використання виключно традиційної форми навчання, саме тому, навчальний процес повинен бути наскрізь пронизаний такими виховними цінностями як: принципи гуманізму, методи навчання, які мають психолого-педагогічне підгрунтя, та духовні властивості особистості, які становлять основу іiї навчальної діяльності. На думку дослідниці, навчальний процес має реалізовуватись за поступовим механізмом, що дозволить сформувати цілісний образ майбутнього психолога та сформувати у нього фундаментальну базу знань, яку він зможе використовувати у подальшій професійній діяльності [10]

Більшість дослідників сходяться в тому, що процес становлення практичного психолога можна, умовно, можна поділити на два періоди, кожен 3 яких складається 3 окремих етапів.

Перший період складається з трьох етапів:

1. Знання - набуття знань загально-психологічного характеру та формування базової термінологічної бази, накопичення базових знань.

2. Уміння - формування навичок роботи з науковою літературою, вміння порівнювати концептуальні основи та різноманітні підходи під час проведення власних психологічних досліджень.

3. Навички - формування навичок роботи з визначеними методиками, математичною статистикою, що дозволить майбутньому психологу не лише збирати інформацію, а й опрацьовувати та інтерпретувати іiі.

Другий період складається з наступних етапів:

1. Ставлення - формування загального позитивного ставлення до власної майбутньої професії, прагнення стати висококваліфікованим фахівцем з урахуванням власної Я-концепції та власних фізичних та розумових можливостей.

2. Майстерність - розвиток здібностей та формування практичних навичок в ході практичної діяльності.

3. Професіоналізм - оволодіння навиками інтеграції базових знань, основами формування, розробки та представлення концептуальних моделей.

4. Творчість - здібність до планування, організації та проведення наукових дослідження, представлення результатів даних досліджень в різних аспектах психологічної діяльності $[10 ; 11 ; 12 ; 13]$.

Сучасна освіта орієнтована на технократію, що виражається в освітньому змісті інформаційних наук та дидактичних та алгоритмічних методах, що відповідають традиційним рамкам психології для навчання прийомам навчання й осмислення знань. У підготовці майбутніх спеціалістів акцент має бути на прийнятті знань, на перетворенні цінностей повідомлення у власні цінності реципієнта, адже лише прийняті людьми цінності становлять основу їх діяльності і регулюють індивідуальну поведінку. При цьому, зовнішні орієнтації можуть бути включені в систему цінностей, якщо: 
- вони не викликають дисонансу моральної орієнтації чи внутрішнього дискомфорту;

- зовнішні цінності не суперечать цінностям, які вже присутні в особистісній структурі;

- нова орієнтація, народжена прийняттям цінностей, дозволяє індивіду задовольнити свої потреби [13].

У аспекті підготовки практичних психологів, які взаємодіють 3 людьми, що мають вади фізичного розвитку, освітня діяльність реалізується з загальним механізмом:

1. Набуття базових знань з психології, формування термінологічної бази.

2. Формування навичок роботи 3 науковою літературою, вивчення передового досвіду в аспекті взаємодії з людьми із обмеженими фізичними можливостями.

3. Вибір методик взаємодії з людьми, що мають обмежені фізичні можливості, формування навичок роботи за визначеними методиками.

4. Відповідальне ставлення до активної взаємодії із людьми, що мають обмежені фізичні можливості.

5. Формування практичних навичок активної взаємодії із людьми, що мають інвалідність, визначення та побудова алгоритмів взаємодії під час надання психологічної консультації або під час психічного супроводу особистості до моменту виведення іiі з психічної кризи.

6. Підвищення рівня професійної майстерності через застосування або розробку нових концептуальних моделей взаємодії з особами, що мають обмежені фізичні можливості.

7. Організація та проведення науково-дослідної роботи щодо визначення ефективних механізмів взаємодії з людьми, що мають обмежені фізичні можливості, представлення даних результатів у публікаціях [4; 13$]$.

Механізм підготовки практичного психолога до активної взаємодії 3 особами, що мають обмежені фізичні можливості є поетапним і лише за умови дотримання даної поетапності, можна говорити про позитивні результати даного типу взаємодії.

Визначаючи специфічність механізму взаємодії 3 людьми, що мають обмежені фізичні можливості, психолог завжди повинен враховувати вікові особливості людини, якій він надає психічну підтримку, або психічний супровід. Так, при роботі з дітьми - інвалідами, практичний психолог повинен організувати роботу таким чином, щоб не лише сприяти психічній підтримці дитини, а й спростити процес введення ऑï в соціум та сприйняття не себе як частини суспільства, яка може з ним активно взаємодіяти. При роботі $з$ даною віковою групою, актуальними стають знання не лише 3 психології, а й 3 педагогіки.

При роботі з людьми працездатного віку, які у вирі життєвих подій набули інвалідність, практична діяльність психолога повинна бути спрямована на 
виведення людини з кризи та подолання нею бар'єру, який виникає за рахунок зміни фізіологічних особливостей. Психолог, в більшій мірі, повинен здійснити психологічний супровід до тих пір, поки людина не стане сприймати себе як частину суспільства, але в новому контексті.

При роботі із людьми похилого віку, що мають фізичні вади розвитку, психолог повинен організувати діяльність на профілактику суїцидальної поведінки, яка проявляється у осіб даної групи значно частіше ніж в інших, та надання психологічної підтримки у розумінні власної значимості $[10 ; 13]$.

Узагальнюючи, можемо вести мову про те, що професійна підготовка психологів до роботи 3 людьми, що мають інвалідність повинна організовуватись під час їх навчання у вищих закладах освіти. Підготовка має поступовий механізм накопичення знань, а робота із людьми, що мають вади розвитку грунтується на базових знаннях, але при застосуванні їх в окремій галузі психологічної науки.

Висновки. Підготовка майбутніх психологів та соціальних працівників здійснюється у закладах вищої освіти. Кожна з підготовок має свої специфічні особливості. Так, при підготовці соціального працівника будь-яка підготовка не дасть позитивних результатів за умови, що людина, яка обрала дану професію не має відповідних людських якостей. Навіть, маючи фундаментальні знання, але, не проявляючи елементарного співчуття до осіб, які мають фізичні вади розвитку, соціальний працівник не зможе надати людині тієї підтримки, на яку вона очікує. Коли ж справа стосується психологів, то лише за умови сформованих базових знань з психології можливе формування навичок активної взаємодії із людьми, які мають обмежені фізичні можливості.

\section{Jimepamypa:}

1. Шарата Н. Г. Теорія і методика управління інноваційно-педагогічною діяльністю у вищих навчальних закладах: дис. ... докторпра пед. наук: 13.00.06. / Шатата Наталія Григорівна. Старобільськ, 2016. 596 с. URL: http://dspace.luguniv.edu.ua/xmlui/bitstream/handle/ 123456789/579/Sharata.pdf?sequen ce=1\&isAllow d=y

2. Екопсихологічні основи соціальної роботи із людьми із інвалідністю. Київ. 2020 URL: http://wcu.org.ua/wp-content.pdf.

3. Попович Г. Підготовка соціальних працівників: широкий профіль чи вузька спеціалізація. Науковий вісник Ужгородського нац. ун-ту : Серія «Педагогіка. Соціальна робота». 2005. № 8. С. 149-151

4. Каблаш В.В. Теоретичні основи професійнох підготовки майбутніх психологів в умовах ЗВО. Вісті. 2019. №1 (24). URL: http://pedagogy.donntu.edu.ua/1-24-2019/kablash-v-vteoretychni-osnovy-profesifjnoi-pidhotovky-majbutnikh-psykholohiv-v-umovakh-zvo/

5. Романовська Л.І. Підготовка майбутніх соціальних педагогів до професійної діяльності та позитивні тенденції такого процесу в Україні. Збірник наукових праць Хмельницького інституту соціальних технологій Університету «Україна». Хмельницьк, 2013. №2(8). С. 223-226

6. Клименюк Н. Формування інклюзивної компетентності в майбутніх соціальних працівників в умовах професійної підготовки. Педагогічні науки: теорія, історія, інноваційні технології. 2017. №1 (65). С. 72-86. 
7. Кизименко Л.Д., Бєдна Л.М. Словник - довідник соціального працівника. URL: http://ipp.lp.edu.ua/Library/004/004.html\#p.

8. Соціальна робота в Україні: Навч. посіб. / І. Д. Зверева, О. В. Безпалько, С Я . Харченко та ін.; За заг. ред.: І. Д. Звєрєвої, Г. М. Лактіонової. К.: Центр навчальної літератури, 2004. $256 \mathrm{c}$

9. Верхоляк М. Ососбливості роботи соціального педагога - гувера 3 дітьми 3 обмеженими можливостями. URL: https://pedcollege.lnu.edu.ua/wp-content/uploads/2015/09.pdf

10. Носков В.І. Проблеми підготовки психологів у системі вищої освіти. Зб. наук. пр. "Психологія". Випуск 4(7). К., 1999. С. 210-219.

11. Ларионова И. А., Дегтерев В. А. Профессиональная подготовка специалистов социальной работы : компетентностный подход. Фундаментальные исследования. 2014. № 11-12. С. 2734-2739.

12. Савельчук I. Б., Бибик Д. Д. Соціальне лідерство як підгрунтя для розвитку партнерської взаємодії в освітньому середовищі університету. Науковий часопис Національного педагогічного університету імені М.П. Драгоманова. Серія 11. Соціальна робота. Соціальна педагогіка. 2018. №25. С.119-125.

13. Ярая Т. А. До питання змісту підготовки майбутніх практичних психологів до роботи зі студентами з обмеженими можливостями. Проблеми сучасної педагогічної освіти. Педагогіка i психологія. 2012. Вип. 37(2). С. 158-163. URL: http://nbuv.gov.ua/UJRN/pspo_2012_37\%282\%29

27

\section{References:}

1. Sharata N. H. (2016). Teoriia i metodyka upravlinnia innovatsiino-pedahohichnoiu diialnistiu u vyshchykh navchalnykh zakladakh [Theory and methods of management of innovation and pedagogical activities in higher educational institutions]. Doctor's thesis. Starobilsk. Retrieved from: http://dspace.luguniv.edu.ua/xmlui/bitstream/handle/123456789/579/Sharata.pdf? sequen $\mathrm{ce}=1 \&$ isAllow $\mathrm{d}=\mathrm{y}$ [in Ukrainian].

2. Ekopsykholohichni osnovy sotsialnoi roboty iz liudmy iz invalidnistiu (2020) [Ecopsychological bases of social work with people with disabilities] Kyiv. Retrieved from: http://wcu.org.ua/wp-content.pdf. [in Ukrainian].

3. Popovych H.(2005). Pidhotovka sotsialnykh pratsivnykiv: shyrokyi profil chy vuzka spetsializatsiia [Training of social workers: broad profile or narrow specialization]. Naukovyi visnyk Uzhhorodskoho nats. un-tu : Seriia «Pedahohika. Sotsialna robota», № 8, 149-151[in Ukrainian].

4. Kablash V.V. (2019). Teoretychni osnovy profesiinokh pidhotovky maibutnikh psykholohiv v umovakh ZVO [Theoretical bases of professional training of future psychologists in the conditions of ZVO ]. Visti,1(24). Retrieved from: http://pedagogy.donntu.edu.ua/1-242019/kablash-v-v-teoretychni-osnovy-profesifjnoi-pidhotovky-majbutnikh-psykholohiv-vumovakh-zvo/ [in Ukrainian].

5. Romanovska L.I. (2013). Pidhotovka maibutnikh sotsialnykh pedahohiv do profesiinoi diialnosti ta pozytyvni tendentsii takoho protsesu v Ukraini [Training of future social educators for professional activity and positive trends in this process in Ukraine]. Zbirnyk naukovykh prats Khmelnytskoho instytutu sotsialnykh tekhnolohii Universytetu «Ukraina». Khmelnytsk, №2(8), 223-226 [in Ukrainian].

6. Klymeniuk N.(2017). Formuvannia inkliuzyvnoi kompetentnosti v maibutnikh sotsialnykh pratsivnykiv $\mathrm{v}$ umovakh profesiinoi pidhotovky [Formation of inclusive competence in future social workers in terms of training ]. Pedahohichni nauky: teoriia, istoriia, innovatsiini tekhnolohii, №1 (65), 72-86 [in Ukrainian].

7. Kyzymenko L.D., \& Biedna L.M. Slovnyk - dovidnyk sotsialnoho pratsivnyka [Dictionnaire - dovidnyk sotsialokhoratsivnik] Retrieved from:http://ipp.lp.edu.ua/Library/004/ 004.html\#p [in Ukrainian]. 
8. Zvereva I. D. (Eds.).(2004). Sotsialna robota v Ukraini: Navch. Posib [Social work in Ukraine: Textbook. Way] Kyiv: Tsentr navchalnoi literatury. [in Ukrainian].

9. Verkholiak M. Ososblyvosti roboty sotsialnoho pedahoha - huvera z ditmy z obmezhenymy mozhlyvostiamy [Features of the work of a social educator - a hoover with children with disabilities]. Retrieved from: https://pedcollege.lnu.edu.ua/wp-content/uploads/2015/09.pdf [in Ukrainian].

10. Noskov V.I. (1999) Problemy pidhotovky psykholohiv u systemi vyshchoi osvity [Problems of training psychologists in the system of higher education]. Zb. nauk. pr. "Psykholohiia", 4(7), 210-219. [in Ukrainian].

11. Laryonova Y. A.(2014). Professyonalnaia podhotovka spetsyalystov sotsyalnoi rabotы : kompetentnostnыi podkhod [Professional training of social work specialists: a competence-based approach]. Fundamentalnble yssledovanyia, № 11-12, 2734-2739. [in Russian]

12. Savelchuk I. B. \& Bybyk D. D. (2018) Sotsialne liderstvo yak pidgruntia dlia rozvytku partnerskoi vzaiemodii v osvitnomu seredovyshchi universytetu [Social leadership as a basis for the development of partnerships in the educational environment of the university ]. Naukovyi chasopys Natsionalnoho pedahohichnoho universytetu imeni M.P. Drahomanova. Seriia 11. Sotsialna robota. Sotsialna pedahohika,25,119-125. [in Ukrainian].

13. Iaraia T. A. (2012). Do pytannia zmistu pidhotovky maibutnikh praktychnykh psykholohiv do roboty zi studentamy z obmezhenymy mozhlyvostiamy [On the content of training future practical psychologists to work with students with disabilities]. Problemy suchasnoi pedahohichnoi osvity. Pedahohika $i$ psykholohiia, №37(2),158-163. Retrieved from: http://nbuv.gov.ua/UJRN/pspo_2012_37\%282\%29_27 [in Ukrainian]. 